\title{
Comparison of the Purifying Performances of Membrane Bioreactor Lab Scale with Activated Sludge Treatment
}

\author{
D. Abdessemed", S. Kiamouche and G. Nezzal
}

Laboratory of the Industrial Process Engineering- Environment, University of Sciences and Technology Houari Boumediene, B.P. 32 El Alia 16111, Bab Ezzouar, Algiers, Algeria

\begin{abstract}
As the principal objective, this present study compares the purifying performances of the membrane bioreactor (MBR) with the conventional activated sludge used from the wastewater treatment plant of Beni Messous (Algiers) with the average characteristics in the chemical oxygen demand being $586 \mathrm{mg} / \mathrm{L}$ and $188 \mathrm{mg} / \mathrm{L}$ in the biochemical oxygen demand and 14 NTU of turbidity. The membrane bioreactor received the domestic wastewater in side stream with an ultrafiltration membrane under the following conditions: mixed liquor suspended solids concentration $4 \mathrm{~g} / \mathrm{L}$; cross flow velocity $\mathrm{U}=4 \mathrm{~m} / \mathrm{s}$ at constant transmembrane pressure 0.8 bar. The results obtained show a better elimination of carbonaceous pollution and suspended solids (SS) for the MBR with COD final value equal to $10 \mathrm{mg} / \mathrm{L}$ and $2 \mathrm{mg} / \mathrm{L}$ in $\mathrm{BOD}_{5}$ and $0,3 \mathrm{mg} / \mathrm{L}$ for SS. For the conventional activated sludge, we obtained a final value equal to $77 \mathrm{mg} / \mathrm{L}$ for the COD and 18 $\mathrm{mg} / \mathrm{L}$ for $\mathrm{BOD}_{5}$ and $25 \mathrm{mg} / \mathrm{L}$ for SS.
\end{abstract}

Keywords: Membrane bioreactor, activated sludge, wastewater, fouling.

\section{INTRODUCTION}

Membrane bioreactor (MBR) technology which combines biological-activated sludge process and membrane filtration has become more popular, abundant, and accepted in recent years for the treatment of many types of wastewater, whereas the conventional activated sludge (CAS) process cannot cope with either composition of wastewater or fluctuations of wastewater flow rate. The membrane bioreactor constitutes a physical barrier blocking the passage to the particulate organic matter similar to the inert fractions coming from the biomass. Also, the membrane bioreactors have the capacity to retain not only the bacteria resulting from the biological treatment but also the faecal coliforms, virus and other micro-organisms coming from the wastewater. This allows a total disinfection of the effluent whatever the load and the fluctuations of the affluent $[1,2]$. Weak production sludge is observed with the membrane bioreactors. This can be due to the often insufficient quantity of substrate taking into account the use of great concentrations in biomass [3], with the shearing generated by the pumping which stresses the bacteria and limit thus the synthesis of new cells [4-6]. The major disadvantage of the membrane bioreactors with is the progressive reduction of the permeate flux. This decline is caused by the phenomenon of concentration polarization and by the membrane fouling. The increase in the concentration of mixed liquor affects the permeate flux conversely. Strohwald et al., show that the permeate flow is linearly

*Address correspondence to this author at the Laboratory of the Industrial Process Engineering- Environment, University of Sciences and Technology Houari Boumediene, B.P. 32 El Alia 16111- Bab Ezzouar- Algiers Algeria; Tel: +213 7718512 43; Fax: +213 212479 19;

E-mail: adjamal@yahoo.com connected to the concentration in biomass (between 20 and $29 \mathrm{~g} / \mathrm{L}$ ) with a factor of 2,66 in the membrane bioreactor with external loop with the increase in the viscosity of mixed liquor [7]. However, Shimizu et al., showed that the linear relation between the concentration of the suspended solid and flux can be observed below $8 \mathrm{~g} / \mathrm{L}$ in the immersed membrane bioreactor, while this same relation is observed with stronger concentration in biomass in the membrane bioreactor with external loop, and a significant shear stresses generated by circulation in the membrane bioreactor with external loop [8]. Whereas, when the rate of circulation increases by 1.5 to $2.6 \mathrm{~m} / \mathrm{s}$, the flux starts to increase by $20 \mathrm{~L} / \mathrm{hm}^{2}$ with $45 \mathrm{~L} / \mathrm{hm}^{2}$. It means that tangential rate can constitute a major factor controlling the flux.

We can compare the performances of the two reactors, one small scale and a large scale, and we can conclude that there are severe differences between lab scale and full scale operation presented in the Table $\mathbf{1}$.

The aim of this present work is to show the comparison between the performances of the membrane bioreactor and the activated sludge treatment used in the wastewater treatment plant.

\section{MATERIAL}

We considered the analysis of treated water resulting from the conventional activated sludge and the membrane bioreactor side stream with external pressure driven membrane filtration.

\section{Presentation of the Wastewater Treatment Plant}

The process of he Beni Messous municipal wastewater treatment plant (WWTP) which is located at $20 \mathrm{~km}$ of the Algiers west is constituted of a primary treatment and secon- 
Table 1. Typical Ranges of Operating Parameters and Conditions for Different Plant Sizes [9]

\begin{tabular}{|c|c|c|c|}
\hline Parameter & Lab Scale & Pilot Plant & Full Scale \\
\hline \hline Volume & $1-10 \mathrm{~L}$ & $100-1000 \mathrm{~L}$ & $10 \mathrm{~m}^{3}$ \\
\hline Operating time & Hours- weeks & Weeks-months & Several years \\
\hline Energy input & $5-20 \mathrm{kWh} / \mathrm{m}^{3}$ & $1-10 \mathrm{kWh} / \mathrm{m}^{3}$ & $0.5-1 \mathrm{kWh} / \mathrm{m}^{3}$ \\
\hline Feed composition & Constant & Constant./ Fluctuating & Fluctuating \\
\hline Hydraulic load & Constant & Constant./Fluctuating. & Fluctuating \\
\hline Temperature & Constant & Lab: constant./field: Fluctuating & Fluctuating \\
\hline
\end{tabular}

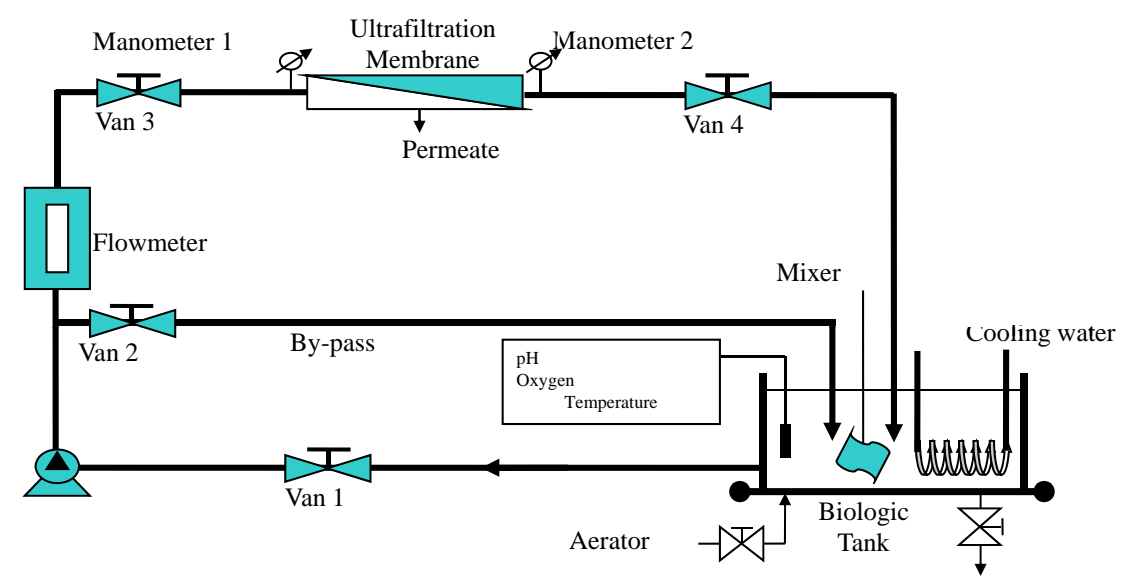

Fig. (1). Experimental Set up.

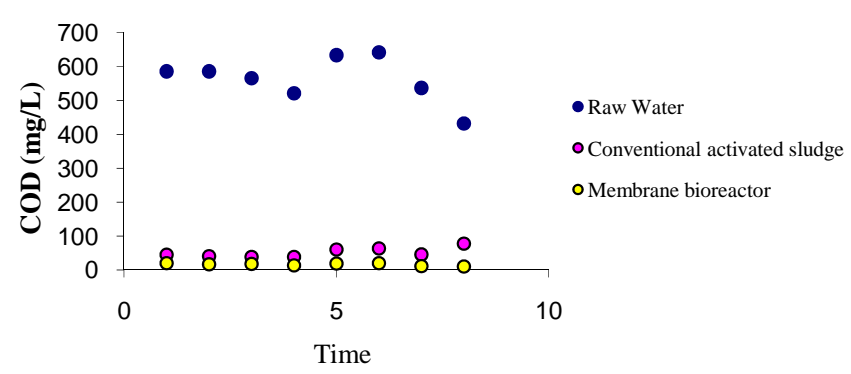

(d)

Fig. (2). COD of the raw water and treated by the conventional activated sludge and the membrane bioreactor.

dary treatment (conventional activated sludge). The treatment capacity of the WTTP was about $50400 \mathrm{~m}^{3} / \mathrm{d}$. The lab scale MBR as shown in (Fig. 1) installed at our laboratory consisted of an effective volume of 30L. An air compressor, type Resun P 1500 was fed to the bioreactor. The bioreactor is sown by activated sludge coming from the WWTP of Beni Messous (Algiers) at mixed liquor suspended solids concentrations (MLSS) equal to $4 \mathrm{~g} / \mathrm{L}$. A tubular inorganic membrane CARBOSEP M2 with cut off $=15 \mathrm{~kg} / \mathrm{mol}$ was used (porous carbon support and membrane layer of $\mathrm{ZrO}_{2}$ ) with an internal diameter $=6 \mathrm{~mm}$, an external diameter $=10 \mathrm{~mm}$. The operating conditions are constant transmembrane pressure $\Delta \mathrm{P}=0,8$ bar and a rate of circulation $\mathrm{U}=4 \mathrm{~m} / \mathrm{s}$. The temperature in the mixed liquor was equal to $28^{\circ} \mathrm{C}$. The membrane bioreactor long term test was running for about 192 hours. The following parameters were analyzed for the raw water and treated water for the membrane bioreactor and conventional activated sludge: $\mathrm{COD}, \mathrm{BOD}_{5}$, suspended solids, turbidity, and $\mathrm{pH}$.

\section{Analysis Methods}

Classical methods for determination of retained parameters have been used (AFNOR standard). The turbidity has been measured with the help of MERK turbidimeter 1500T which was calibrated. The $\mathrm{pH}$ was measured with a calibrated $\mathrm{pH}$ meter, HANNA type 211. The COD and BOD were measured with AFNOR methods.

\section{RESULTS AND DISCUSSIONS}

Comparison of the purifying performances of the membrane bioreactor and the conventional activated sludge

\section{Chemical Oxygen Demand (COD)}

Fig. (2) represents the results of the raw water and water treated of the COD resulting from the conventional activated sludge and the membrane bioreactor.

The membrane bioreactor gave COD removals up to $97 \%$ while the conventional activated sludge achieved removals of 


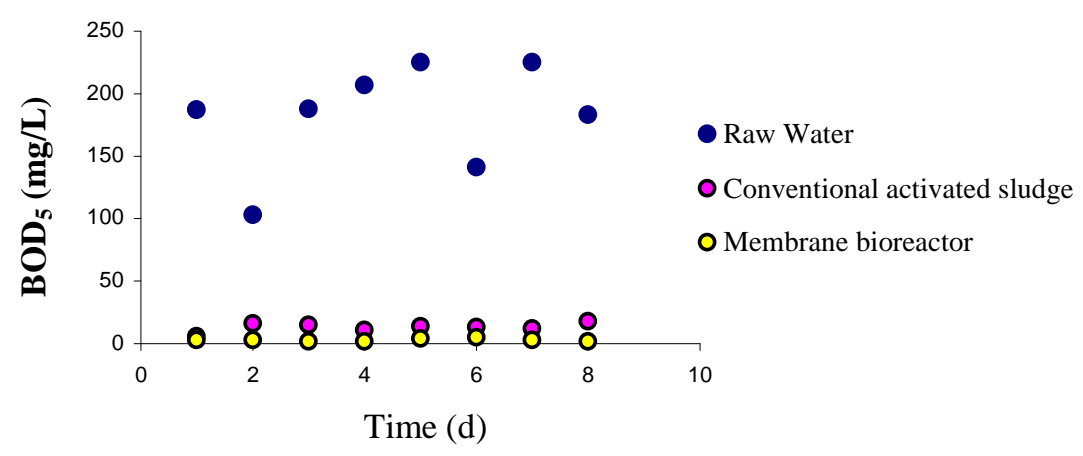

Fig. (3). $\mathrm{BOD}_{5}$ of the raw water and treated water by the conventional activated sludge and the membrane bioreactor.

$91 \%$. These differences in results between BA and BRM can be due to the presence of biomass, proteinic compounds or dissolved and/or particulate organic matter residues in treated water, resulting from the conventional activated sludge. On the other hand during the treatment with the MBR, the ultrafiltration membrane allowed to retain all the purifying biomass as well as all the particulate organic matter, thus only the dissolved matter which could not be degraded by the bacteria in the treated water. Gander et al. reported that membrane contribution to the removal of organic matter was approximately $30 \%$, this roughly equals the insoluble fraction that was removed via active biomass [10]. Knowledge about COD removal mechanisms that occur when mixing an activated sludge with real wastewater is still scarce. The microbial response to dynamic conditions in a real wastewater treatment unit can be different from simple increase in cell number (i.e., growth of microbial population), and include other substrate-removal mechanisms like sorption, accumulation, and storage [11]. There have been several investigations on treatment efficiencies of MBR and CAS processes operating under comparable conditions that have shown significantly improved performance of an MBR in terms of COD, and SS removals. There are several factors that may contribute to the lower organic carbon content of MBR effluents as compared to CAS processes, like longer retention times, smaller floc sizes, etc. Côté et al. attributed the improved COD removal to the avoidance of biomass washout problems commonly encountered in activated sludge process, as well as to complete particulate retention by the membrane [12]. Membrane rejection of a significant amount of soluble organic molecules and colloids makes their removal more effective due to a higher lyses activity in the reactor induced by elevated concentrations of these compounds. Higher sludge ages that are achieved by long sludge retention time (SRT) allow more complete mineralization of biodegradable raw water organics, but also an adaptation of microorganisms to less biodegradable compounds. Therefore, biomass can acclimatize to wastewater without being restricted to fast-growing and floc-forming microorganisms. Flocs in a bioreactor were found to be smaller [13], which can explain enhanced mass transfer for both oxygen and carbon, thus enabling a higher removal rate and more adaptability to changes in the influent quality and quantity [14]. In another study, it was demonstrated that the flocs were more active and displayed greater species diversity [15]. The overall capacity of biomass to degrade different carbon substrates does not change significantly at different SRTs, which con- firms that MBR is capable of degrading a wide variety of carbon substrates in a similar fashion.

This robustness of MBR treatment regarding turbidity and organic matter removals was confirmed in several studies [16]. Xing et al. recorded high treatment efficiency regardless of the absolute level of sludge concentration [17].

\section{Biochemical Oxygen Demand (BOD $\left.)_{5}\right)$}

The MBR appeared to be a very effective of $\mathrm{BOD}_{5}$ removal with efficiency up to $98 \%$ against $93 \%$ for the conventional activated sludge represented by Fig. (3).

We also note a fluctuation in the removal efficiency of $\mathrm{BOD}_{5}$ for the conventional activated sludge, on the other hand for the membrane bioreactor, this last remained constant during all the period of the study. There are still very satisfactory results obtained with the membrane bioreactor due to the stage of filtration.

\section{Suspended Solids (SS)}

Suspended solids can be removed by the MBR, a quasi complete elimination with $99 \%$ abatement rate of the suspended solid against an average elimination of $86 \%$ for the conventional activated sludge represented by Fig. (4).

The capacity of the ultrafiltration membrane is to retain all the insoluble matters in water, even those of very low dimensions like the colloidal particles. Whereas for the conventional activated sludge, the settling makes it possible to eliminate only the settable particles. The particles with low density or dimension are not precipitated. They are found consequently in the treated water.

\section{The Turbidity}

Fig. (5) showed the evolution of turbidity of the raw water and treated water by activated sludge and membrane bioreactor.

The best reduction in turbidity obtained for treated water by the membrane bioreactor, with a quasi null turbidity, and 2.77 NTU for the conventional activated sludge. This is due to a complete retention of particulate matter by the membrane, there are no suspended solids found in the MBR effluent, unlike the effluent of a conventional process. The ultrafiltration membrane can capture all suspended solids in the reactor because of its fine pore size. Therefore, nonbiodegradable organic compounds are removed through filtration of particulates and discharged with the sludge. 


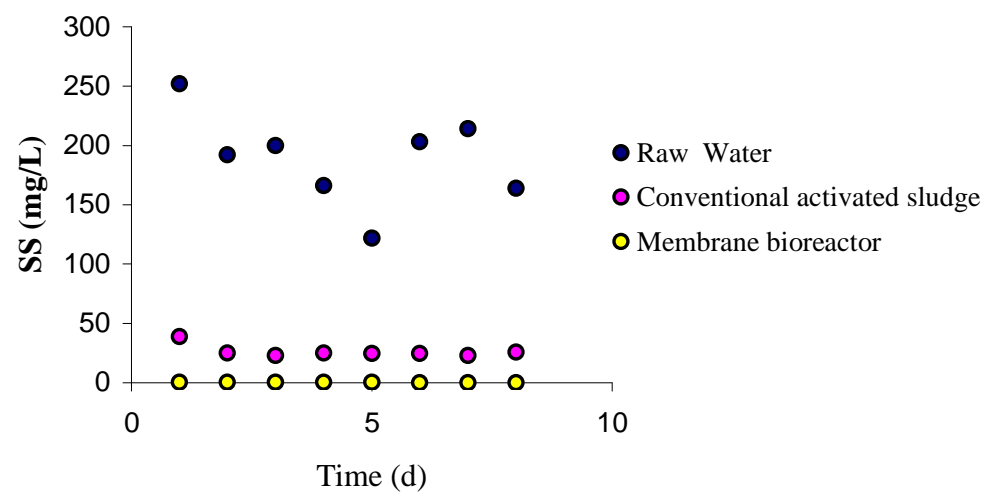

Fig. (4). Concentration in Suspended Solids of the raw water and treated water resulting from the conventional activated sludge and the membrane bioreactor.

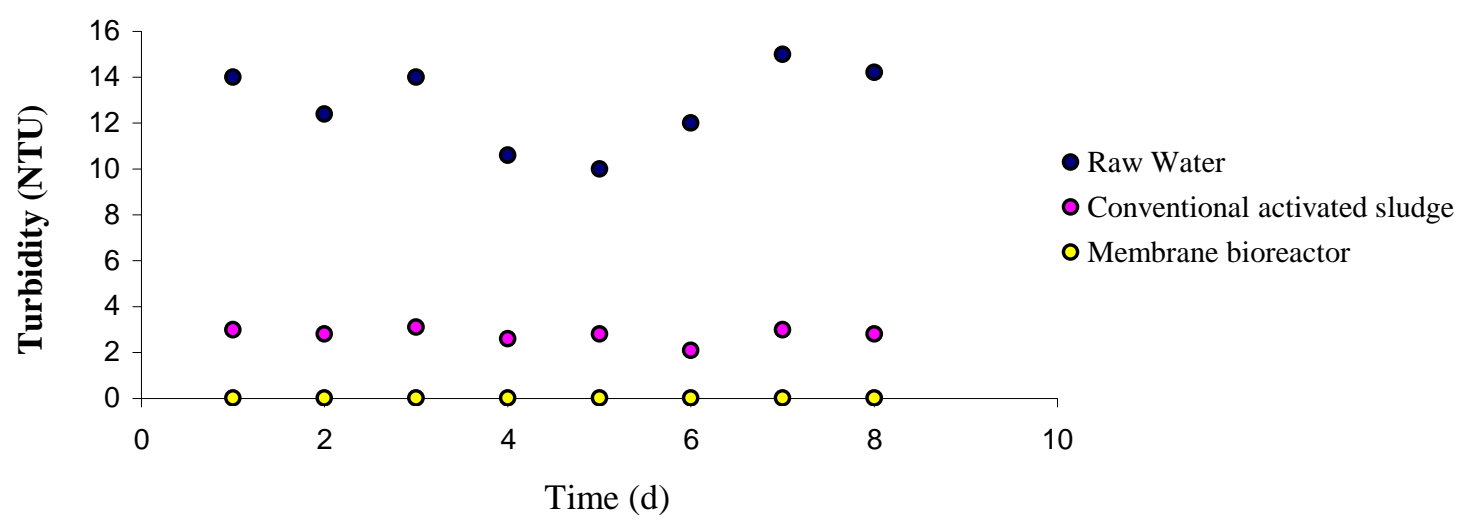

Fig. (5). Turbidity of the raw water and the water treated by two processes conventional activated sludge and membrane bioreactor.

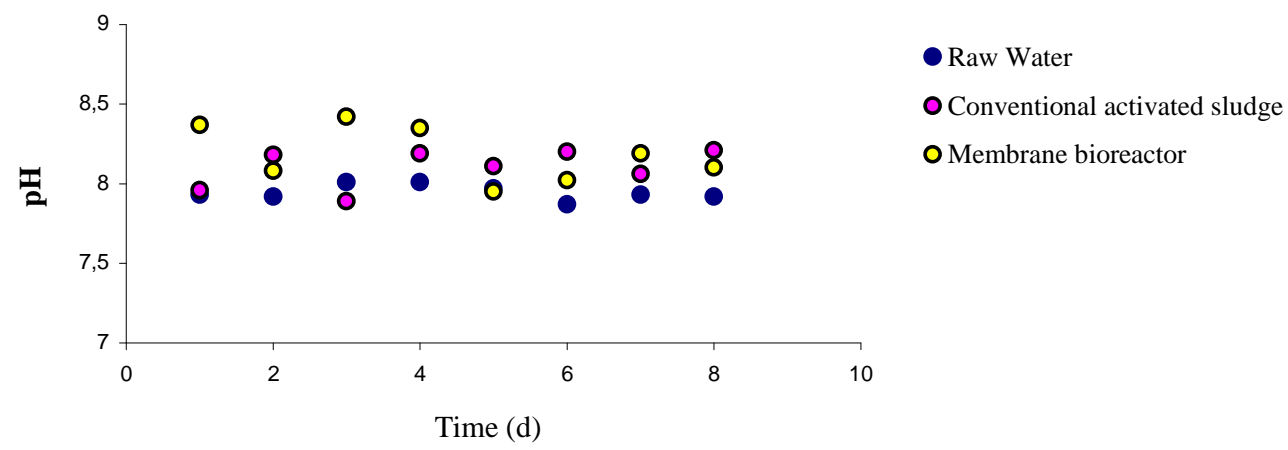

Fig. (6). $\mathrm{pH}$ of the raw water and treated water resulting from the two processes: activated sludge and membrane bioreactor.

pH

Fig. (6) represents the values of the $\mathrm{pH}$ of the raw water and treated water by the conventional activated sludge and membrane bioreactor.

The $\mathrm{pH}$ of the raw water was maintained at an average value of 7.82, we observe a light rise of $\mathrm{pH}$ of treated water 8.1 for the conventional activated sludge and 8.2 for the membrane bioreactor. These values obey the rejection standards $(6<\mathrm{p} \mathrm{H}<9)$. Table 2 gives the results obtained after the treatment of domestic waste water on the one hand, with the membrane bioreactor and on the other hand with the conventional activated sludge.

\section{CONCLUSION}

Membrane bioreactor technology is used in cases where demand on the quality of effluent exceeds the capability of the conventional activated sludge. Although the membrane bioreactor capital and operational costs exceed the costs of conventional process, it seems that the upgrade of conventional process occurs even in cases when conventional treatment works well. It can be related with increase of water 
Table 2. Comparison of the Purifying Performances of the Membrane Bioreactor and the Conventional Activated Sludge

\begin{tabular}{|c|c|c|c|c|c|}
\hline Parameters & $\begin{array}{c}\text { Average } \\
\text { Concentration } \\
\text { of Waste Water }\end{array}$ & $\begin{array}{c}\text { Average Concentration } \\
\text { of Treated Water MBR }\end{array}$ & $\begin{array}{c}\text { Average Concentration } \\
\text { of Treated Water AS }\end{array}$ & $\begin{array}{c}\text { Removal } \\
\text { Elimination } \\
\text { MBR }(\%)\end{array}$ & $\begin{array}{c}\text { Removal } \\
\text { Elimination } \\
\text { AS }(\%)\end{array}$ \\
\hline \hline $\begin{array}{c}\mathrm{COD} \\
\left(\mathrm{mgO}_{2} / \mathrm{L}\right)\end{array}$ & $563 \pm 4$ & $16 \pm 2$ & $50 \pm 3$ & $97 \pm 5$ & $91 \pm 4$ \\
\hline $\begin{array}{c}\mathrm{BOD}_{5} \\
\left(\mathrm{mgO}_{2} / \mathrm{L}\right)\end{array}$ & $182 \pm 3$ & $3 \pm 1$ & $13 \pm 2$ & $88 \pm 3$ & $83 \pm 3$ \\
\hline $\mathrm{SS}(\mathrm{mg} / \mathrm{L})$ & $189 \pm 3$ & 0.2 & $26 \pm 8$ & $99 \pm 4$ \\
\hline
\end{tabular}

price and need for water reuse as well as with more stringent regulations on the effluent quality. It seem clear that the use of the MBR had some important advantages like the higher removal efficiency and a higher quality effluent. Indeed, the membrane bioreactor was able to treat wastewater with high removal efficiency (about $96 \%$ ) in COD, more than $98 \%$ of the $\mathrm{BOD}_{5}$ like $99.9 \%$ of $\mathrm{SS}$; with the concentrations of the treated water about 10 to $20 \mathrm{mgO}_{2} / \mathrm{L}$ for the COD, 2 to 5 $\mathrm{mgO}_{2} / \mathrm{L}$ for the $\mathrm{BOD}_{5}$ and less than $0.3 \mathrm{mg} / \mathrm{L}$ for $\mathrm{SS}$. Whereas the conventional activated sludge used in the WTTP of Beni Messous, was able to eliminate only 82.2 to $93 \%$ from the COD, 90 to $96.8 \%$ of the $\mathrm{BOD}_{5}$ and 79.7 to $89.3 \%$ of SS. The concentrations of treated water ranging between 38 and $77 \mathrm{mgO}_{2} / \mathrm{L}$ for the COD, 6 and $18 \mathrm{mgO}_{2} / \mathrm{L}$ for the $\mathrm{BOD}_{5}$ and 22.8 and $38.9 \mathrm{mg} \mathrm{SS} / \mathrm{L}$. In conclusion, MBR represents an efficient and cost effective process that copes excellently with the growing needs for transforming wastewater into clean water that can be returned to the hydrological cycle without detrimental.

\section{REFERENCES}

[1] A. G. Fane, S. Chang, and E. Chardon, " Submerged hollow fibre membrane module -design options and operational considerations", Desalination, vol. 46, pp. 231-236, 2002.

[2] A. Masse, "Bioréacteur à membranes immergées pour le traitement des eaux résiduaires urbaines spécificités physico-chimiques du milieu biologique et colmatage", Thesis, The National Institute of Applied Sciences, Toulouse, France, 2004.

[3] K. Yamamoto, M. Hiasa, T. Mahmood, and T. Matsuo, "Direct solid-liquid separation using hollow fibber membrane aeration tank", Water Res, vol. 21, no 10, pp. 43-50,1989.

[4] R. Witzig, W. Manz, S. Rosenberger, U. Kruger, M. Kraume, and U. Szewzyk, "Microbiological aspects of bioreactor with submerged membrane for aerobic treatment of municipal wastewater", Water Res, vol. 36, pp. 394-402, 2002.

[5] K. H. Choo, and C. H. Lee, "Membrane fouling mechanism in the membrane-coupled anaerobic bioreactor", Water Res, vol. 30, no. 8, pp. 1771-1780,1996.
[6] I. J. Kang, S. H. Yoon, and C. H. Lee, "Comparison of the filtration characteristics of organic and inorganic membranes in a membranecoupled anaerobic bioreactor", Water Res, vol. 36, pp. 1803-1813, 2002.

[7] N. K. H. Strohwald, "Application of the ADUF Process to Brewery Effluent on a Laboratory Scale", Water Sci Technol, vol. 25, no. 10, pp. 95-105, 1992.

[8] Y. Shimizu, Y. Okuno, K. Uryu, S. Ohtsubo, and A. Watanabe," Filtration characteristics of hollow fibber microfiltration membrane used in membrane bioreactor for domestic wastewater treatment", Water Res, vol. 30, no. 10, pp. 2385-2392, 1996.

[9] M. Kraume, D. Wedi, J. Schaller, V. Iversen, and A. Drews, "Fouling in MBR: What use are lab investigations for full scale operation", Desalination vol. 236, pp. 94-103, 2009.

[10] M. A. Gander, B. Jefferson, S. J. Judd, " Membrane bioreactors for use in small wastewater treatment plants: membrane materials and effluent quality", Water Sci Technol, vol. 41, pp. 205-211, 2000.

[11] A Carucci, D. Dionisi, M Majone, E. Rolle, and P. Smurra. "Aerobic storage by activated sludge on real wastewater", Water Res, vol. 35, pp. 3833-3844, 2001.

[12] P. Côté, H. Buisson, C. Pound, and G. Arakaki, "Immersed membrane activated sludge for the reuse of municipal wastewater", Desalination, vol. 113, pp. 189-196, 1997.

[13] X. Huang, P. Gui, Y. Qian, "Effect of sludge retention time on microbial behaviour in a submerged membrane bioreactor", Proc Biochem., vol. 36, pp. 1001-1006, 2001.

[14] D. D. Sun, C. T. Hay, and S. L. Khor, "Effects of hydraulic retention time on behaviour of start-up submerged membrane bioreactor with prolonged sludge retention time", Desalination, vol. 195, pp. 209-225, 2006.

[15] N. Cicek, J. P. Franco, M. T. Suidan, V. Urbain, and J. Manem, "Effect of solid retention time on the performance and biological characteristics of a membrane bioreactor", Water Environ Res, pp. vol. 71, 64-70, 2001

[16] X. J. Fan, V. Urbain, Y. Qian, and J. Manem, "Nitrification and mass balance with a membrane bioreactor for municipal wastewater treatment", Water Sci Technol, vol. 34, pp. 29$136,1996$.

[17] C. H. Xing, E. Tardieu, Y. Qian, and X. H. Wen, "Ultrafiltration membrane bioreactor for urban wastewater reclamation", J. Membr Sci, vol. 177, pp. 73-82, 2000.

(C) Abdessemed et al.; Licensee Bentham Open.

This is an open access article licensed under the terms of the Creative Commons Attribution Non-Commercial License (http://creativecommons.org/licenses/by-nc/3.0/) which permits unrestricted, non-commercial use, distribution and reproduction in any medium, provided the work is properly cited. 